\title{
The role of customer awareness in promoting firm sustainability and sustainable supply chain management
}

Article

Accepted Version

Gong, M., Gao, Y., Koh, L., Sutcliffe, C. and Cullen, J. (2019) The role of customer awareness in promoting firm sustainability and sustainable supply chain management. International Journal of Production Economics, 217. pp. 88-96. ISSN 0925-5273 doi: https://doi.org/10.1016/j.ijpe.2019.01.033 Available at https://centaur.reading.ac.uk/82215/

It is advisable to refer to the publisher's version if you intend to cite from the work. See Guidance on citing.

To link to this article DOI: http://dx.doi.org/10.1016/j.ijpe.2019.01.033

Publisher: Elsevier

All outputs in CentAUR are protected by Intellectual Property Rights law, including copyright law. Copyright and IPR is retained by the creators or other copyright holders. Terms and conditions for use of this material are defined in the End User Agreement.

www.reading.ac.uk/centaur 
Central Archive at the University of Reading

Reading's research outputs online 


\title{
The Role of Customer Awareness in Promoting Firm Sustainability and Sustainable Supply Chain Management
}

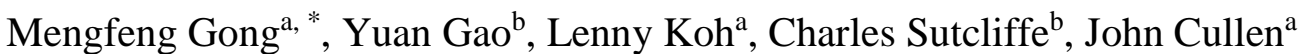

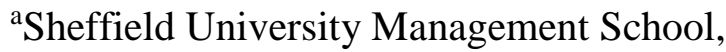 \\ The University of Sheffield \\ Conduit Road, Sheffield S10 1FL, UK \\ ${ }^{\mathrm{b}} \mathrm{ICMA}$ Centre \\ Henley Business School \\ University of Reading \\ Whiteknights \\ Reading \\ RG6 6BA
}

28 January 2019

* Corresponding author: Mengfeng Gong (mgong2@sheffield.ac.uk 


\title{
The Role of Customer Awareness in Promoting Firm Sustainability and Sustainable Supply Chain Management
}

\begin{abstract}
In light of the growing complexity of globally dispersed, multi-tier supply chains; sustainable supply chain management (SSCM) has become instrumental in the quest for achieving sustainability compliance along the supply chain. This study investigates how sustainability capability develops within a firm, and then extends to SSCM. Using a fixed-effect model and a global dataset of 2,206 firms between 2002 and 2015, this study shows that a firm's information environment, proxied by their customers awareness, has a significantly positive effect on their sustainability performance, and on their implementation of SSCM. Our analysis suggests that the influence of a firm's information environment on a firm's SSCM performance is mediated by the firm's own sustainability capability. We also find that this relationship is affected by stakeholder engagement. This research is relevant because, by investigating the factors that influence the development of SSCM, it provides guidance for firms that wish to achieve sustainability improvements in their supply chains during an era when the natural environment, social responsibility and the related strategic opportunities have increased in importance.
\end{abstract}

Keywords: Sustainable supply chain management; Information environment; Customer awareness; Stakeholder engagement. 


\section{Introduction}

Firms' sustainability has become increasingly important for firms as they face intense scrutiny from diverse stakeholders, and has been advocated as a key component of the social contract between business and society (Henriques and Sadorsky, 1999, Gold et al., 2015). Over decades this trend has been further extended beyond the boundaries of a focal firm to its supply chain partner's sustainability as non-adherence to sustainability standards across multi-tiers supply chain bears the risk of negative publicity for global brands. According to this "chain liability effect" (van Tulder et al., 2009), the focal firm can be "held accountable for actions that take place within their globally dispersed supply chains" (Wilhelm et al., 2016a). For instance, Mattel has experienced a significant loss of market share and reputational damage by recalling millions of toys with toxic paint sourced by Mattel's suppliers (Tang, 2008). Similarly, customers of high-street clothing retailers had a well-known battle against retailers whose subtier suppliers discharged hazardous chemicals into major rivers in China (Greenpeace, 2011). In 2011 the Brazilian government charged Zara's parent company, accusing it of "sweatshoplike working conditions in a subcontractor's facilities of Zara's main supplier, AHA" (Wilhelm et al., 2016b). At the beginning of 2010 Nestlé changed its palm oil sourcing because an Indonesian sub-tier supplier engaged in illegal deforestation (Langheinrich and Karjoth, 2010).

The greater is the extent to which firms rely on supply chains partners, the greater is the extent to which their environmental and social sustainability depends on their supply chain partners. Managing sustainability practices for supply chains or sustainable supply chain management (SSCM) is a challenging task. Sub-tier suppliers may also lack information and expertise on the sustainability issues that concern customers; and tend to have a tenuous relationship with the focal firm (Grimm et al., 2014, Wilhelm et al., 2016a). Although firms generally incorporate sustainability into their own operations, it is unclear how their sustainability is 
extended to their supply chain partners via SSCM; as is the identity of the factors that drive and influence this process. Consequently, there is a need to develop a better understanding about why and when firms extend their sustainable reach into the supply chain.

We examine whether a firm's information environment is able to drive the firm towards the adoption of SSCM. More specifically, we study whether SSCM activities are enhanced if they are conducted by firms with more consumer awareness. We also investigate whether the impact of consumer awareness is increased for firms with greater stakeholder engagement. We contribute to the literature by addressing two research questions. First, to what extent does customers' awareness influence a firm to meet their customers' sustainability expectations, and to diffuse sustainability down to their suppliers via SSCM? Second, to what extent does greater stakeholder engagement affect a firm's response to customer awareness?

To answer these research questions, we develop a conceptual model linking a firm's sustainability capability, SSCM, customer awareness and stakeholder engagement; which we test on a large, diverse cross-country and cross-industry sample of 2,206 firms for fourteen years (2002-2015). We argue that this research is relevant for the management of growing complex, globally dispersed and multi-tier supply chains because it clarifies how sustainability develops within a firm, evolves from internal to external practices via SSCM and what factors drive, enable and influence this process, thereby providing the basis for further research. Improving the understanding of how SSCM develops is critical if firms are to augment their ability to deliver further social and environmental improvements in their supply chains (e.g. Zhu et al., 2012, Zhu et al., 2013, Gualandris and Kalchschmidt, 2014). 
This paper is organized as follows. In Section 2 the theoretical background and hypotheses are developed. Section 3 introduces and defines the sample and the variables used to test our hypotheses. This is followed in Section 4 by the descriptive statistics and empirical results. Section 5 has our discussion and conclusions. Finally, Section 6 outlines avenues for future research.

\section{Theoretical Background and Hypothesis Development}

\subsection{Defining SSCM}

Sustainable supply chain management has been defined by Seuring and Müller (2008, p. 1700) as: "the management of material, information and capital flows as well as cooperation among companies along the supply chain while taking goals from all three dimensions of sustainable development, i.e., economic, environmental and social, into account which are derived from customer and stakeholder requirements." Together with the economic aspects, this definition highlights the environmental and social aspects of SSCM, as well as the need for cooperation among firms along the supply chain, and meeting stakeholder requirements not just those of the focal firm. Thus, SSCM is considered for the whole supply chain of a multi-tier system and their related stakeholders.

There are two streams of research on SSCM. One stream discusses the implementation of a code of conduct or standards such as ISO 9000, ISO14001 and SA 8000 (Corbett and Kirsch, 2001, Delmas, 2001, Corbett, 2006, Mueller et al., 2009, Orzes et al., 2017); Waste Electrical and Electronic Equipment and Restriction of the Use of Certain Hazardous Substances (Koh et al., 2012); and the application of due diligence on conflict minerals (Hofmann et al., 2018). A second stream of research on SSCM discusses proactive sustainable projects implemented in multi-tier supply chains (Plambeck et al., 2012, Plambeck, 2012, Grimm et al., 2014, Lee et 
al., 2014, Morais and Silvestre, 2018). Plambeck et al. (2012) conducted a series of studies of Walmart which, together with third parties such as NGOs, implemented sustainability initiatives covering its multiple levels of supply chain partners. Plambeck et al. (2012) emphasize that it is important to cascade the diffusion of sustainability and facilitate learning among multi-tier suppliers. Further, sustainability in SSCM needs to consider approaches which effectively involve the monitoring role of external stakeholders. ${ }^{1}$

Some studies indicate a link between a firm's own sustainability (internal) and SSCM performance (external); suggesting that the former fosters the latter, with internal practices providing a foundation for the development of externally oriented SSCM activities. For instance, Gualandris and Kalchschmidt (2014) suggest that adopting internal sustainable process management benefits external sustainable supply management. Gavronski et al. (2011) have suggested that collaboration by firms with their supply chain partners is a higher-order ability that rests on abilities arising from green manufacturing processes adopted by the firm.

\subsection{Customer Awareness and SSCM}

In developing our prediction that a firm's information environment (customer awareness) is an essential motivation for firms to pursue their own sustainability and SSCM performance; the existing literature has established two facts. Customers consider a firm's sustainability activities, including SSCM, when making purchase decisions; and consumers are often not fully aware of a firm's SSCM activities.

There is a substantial theoretical and empirical literature devoted to the issue that sustainability is associated with superior financial performance. For example, previous research suggests that

\footnotetext{
${ }^{1}$ We thank an anonymous reviewer for this point.
} 
firms engage in profit maximizing sustainable practices (Baron, 2001, McWilliams and Siegel, 2001), and "do well by doing good." At the heart of these views is the central role of stakeholder theory (McWilliams and Siegel, 2001, Jenkins, 2004, Freeman and Velamuri, 2006, O'Riordan and Fairbrass, 2008, Park and Ghauri, 2015, Scherer, 2018). Stakeholder theory suggests firms increasingly interpret sustainability in terms of the interests of various groups of stakeholders (e.g. consumers, employees, investors, communities, government, environment, etc.), and their sustainability efforts are influenced by the strong belief that these stakeholder groups will favour firms with a good sustainability performance (Sen and Bhattacharya, 2001). Schuler and Cording (2006) argue that a firm with a better sustainability reputation is rewarded by stakeholders through investment, consumption, higher productivity and less regulatory pressure; and so should perform better when competing in the market. Mutual trust and cooperation with stakeholders also reduce the implicit and explicit costs of negotiating and contracting. From a resource dependence perspective, Frooman (1999) suggests stakeholders affect organizational behaviour by influencing access to key resources, i.e. they manipulate the flow of resources to the organization. Freeman (1984) confirms that stakeholders have the capacity to mobilize public opinion in favour of, or in opposition to, an organization's sustainability performance.

We focus on the customer channel, and examine the role of customer awareness in promoting firm sustainability and SSCM performance. While other channels are also affected by the information environment, the consumer channel offers a promising area to study because consumer awareness influences a firm's sales and its financial performance (see, for example,Sen and Bhattacharya, 2001, Bhattacharya and Sen, 2004, Servaes and Tamayo, 2013). Some of this research suggests that consumers are willing to pay a higher price for the products of firms with more sustainable engagement; and other research suggests that consumers are 
more likely to purchase goods from firms that are more socially responsible. The increase in society's expectations of the social responsibilities of firms has led to increased demand for environmentally friendly goods and services, and created a market opportunity for firms with a strong sustainability performance (Hart, 1995, Berrone and Gomez-Mejia, 2009). For example, a survey found that over $40 \%$ of executives thought the green movement and the associated increase in customer demand for green products and services offered substantial market opportunities (de Villiers et al., 2011).

Even if the majority of studies find a positive relationship between sustainable initiatives and firm value, the concern is that sustainable activities are costly, and the costs do not always outweigh the benefits. This is particularly the case for a focal firm managing the sustainability of its supply chain partners. There are several factors which reduce the incentive for firms to greater engagement in SSCM. First, the dissemination of sustainability standards along a supply chain requires managerial effort and extra costs for the focal firm. For example, subtier suppliers are often located in countries where environmental and social regulations are less demanding, and geographical and institutional distance compounds the challenge of managing such relationships (Esty and Winston, 2009). Sub-tier suppliers may lack information, resources and expertise on the sustainability issues that concern customers; and tend to have an unstable relationship with the focal firm (Grimm et al., 2014, Wilhelm et al., 2016a). Second, customers have limited information on the sustainability performance of the sub-tier suppliers of a focal firm (Choi and Hong, 2002). As articulated by Bhattacharya and Sen (2004), Servaes and Tamayo (2013) and Schuler and Cording (2006), if customers are unaware of the sustainability performance of the focal firm, they cannot react to this performance. The lack of customer awareness of the sustainability initiatives of the focal firm often makes these efforts in vain. McWilliams and Siegel (2001) predict a positive correlation between advertising 
intensity and sustainability performance as, to benefit from their sustainability efforts, firms need to ensure their customers are informed. Conversely, a more transparent information environment between a focal firm's suppliers and customers, and the higher returns to engaging in SSCM, motives the focal firm to be more active in managing their sustainability and passing through the sustainability standard to the next tier.

All these arguments lead to our main prediction that customer awareness is the essential enabler for a firm to improve its own sustainability capability and SSCM. Thus, we hypothesize that:-

H1: High customer awareness has a positive impact on suppliers'sustainability performance. H2: High customer awareness has a positive impact on the dissemination of sustainability to the upstream supply chain via SSCM.

Bhakoo and Choi (2013) and Zu and Kaynak (2012) suggest that a major reason for the reluctance of focal firms to be more active on sustainability issues is a lack of information, resources and expertise on this topic, leading to a low capability for achieving sustainability in their operations. Zhu et al. (2012) suggest that the capability of the focal firm to improve sustainability in their internal operations (e.g. expert staff to manage sustainability) is an important prerequisite for them to be responsive to the increased customer expectation to diffuse sustainability to supply chain partners. The information asymmetry between customers and the focal firm's suppliers is larger than that between customers and the focal firm. This provides the focal firm with more scope to conceal their difficulties in managing the sustainability performance of their supply chain than they have in concealing their own sustainability performance from their customers. Therefore, resource availability plays out particularly strongly in managing supply chain sustainability. Without experts and resources to 
implement the focal firm's own sustainability operation, their capability to disseminate sustainability via SSCM is compromised.

Thus, we hypothesize: -

H3. The impact of customer awareness on the focal firm's performance to disseminate sustainability to their supply chain is mediated by the focal firm's own sustainability capability.

Greater stakeholder engagement by the focal firm increases the public visibility of sustainability issues concerning the firm (Carter and Easton, 2011, Cheng et al., 2014, Eccles et al., 2014). This increases the incentive of the firm's managers to improve their internal control mechanisms to comply with stakeholders' sustainability wishes, and avoid a negative response. (Vilanova et al., 2009, Kannan, 2017). Empirically, Jo and Kim (2007, 2008) report that enhanced transparency through frequent and voluntary interaction with stakeholders decreases the information asymmetry between insiders and outsiders, encourages compliance with the sustainability requirements of broader stakeholders, and discourages managerial rent extraction. Bénabou and Tirole (2010) report that better stakeholder engagement helps firms adopt a more long-term perspective by discouraging short-term opportunistic behaviour. Similarly, Parmigiani et al. (2011) suggest that firms which are expected to justify their supply chain decisions to stakeholders, improve their sustainability performance. The higher the expectation, the higher is the motivation of the firm to invest in SSCM. Gualandris et al. (2015) suggest that stakeholder engagement determines the level and depth of supplier monitoring, with firms that are less visible to the public tending to wait longer to establish links with other members of the supply chain. 
Therefore, we argue that greater stakeholder engagement reduces the information gap between customers and the focal firm, which increases the demand from customers for socially responsible behaviour and the returns to focal firms from engaging in such behaviour. This motivates focal firms to be more active in disseminating sustainability to their supply chain.

This leads to the hypothesis:

H4. Stakeholder engagement improves the sustainability performance relationship between the focal firm and its supply chain partners.

The effects of customer awareness and stakeholder engagement on the focal firm are shown in Figure 1.

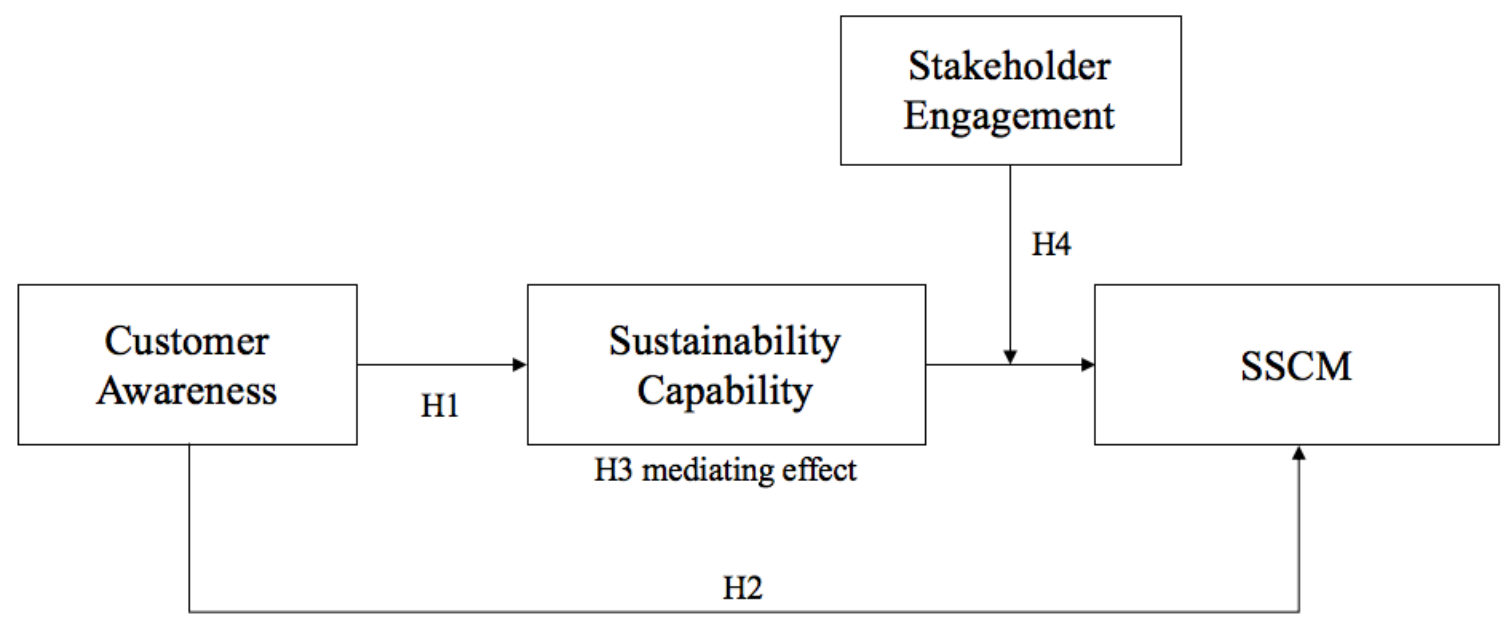

Figure 1: Effects of customer awareness and stakeholder engagement the focal firm's own sustainability and SSCM performance.

\section{Data and Variables}

In previous studies SSCM data has been obtained through surveys. However, this type of data can be biased as "respondents may tend to present a socially desirable image of themselves or their companies" (Berrone et al., 2013). Instead, we use the Thomson Reuters ASSET4 
database, which contains publicly available information, and has a reputation as one of the most reliable and trustworthy data sources for sustainable analysis (Ioannou and Serafeim, 2012, Chatterji and Fabrizio, 2014, Semenova and Hassel, 2015). Thomson Reuters ASSET4 is a Swiss-based firm that specializes in providing "objective, relevant, auditable, and systematic ESG information" (Cheng et al., 2014) Each year specially trained research analysts employed by Thomson Reuters ASSET4 collect more than 750 individual pieces of information per firm from publicly available data (annual report, news, and other media). ASSET4 contains firms in the MSCI World, MSCI Europe, STOXX 600, NASDAQ 100, Russell 1000, S\&P 500, FTSE 100, ASX 300, and MSCI Emerging Market indices. Due to its robust data measurement and large global coverage, many researches have employed the ASSET4 database to establish customizable benchmarks for the assessment of sustainability; and this has recently been extended to measure sustainable supply chain performance (Ortas et al., 2014, Semenova and Hassel, 2015, Ferrell et al., 2016, Liang and Renneboog, 2017).

To be included in the final sample, we merge data from the ASSET4 database with accounting and financial data from the Worldscope database, which measures our control variables. Each firm-year observation was required to have no missing values for any variable, and there are 16,493 firm-year observations for which we have all the required data. The final sample consists of 2,206 firms across different countries and industries. The first year in the ASSET4 database is 2002, and our data covers the 2002-2015 period.

\subsection{Dependent variable}

Following Ortas et al. (2014), when using the ASSET4 database, we employ the same threestep procedure to measure the SSCM performance of the focal firm. First, an intensive search of the ASSET4 database identified all the performance indicators of supply chain sustainability 
(see Appendix A). Second, factor analysis was applied to these indicators to extract the SSCM variable for use in our analysis. As these key performance indicators are binary, exploratory factor analysis based on a Pearson correlation matrix can be misleading as it is only appropriate for continuous unimodal data. Thus, in line with Ortas et al. (2014), we compute the matrix of tetrachoric correlations for the factor analysis. The eigenvalue of our extracted factor is 4.609 , and is the only extracted factor with an eigenvalue above one. Because only one component is extracted we do not apply Kaiser-Guttman factor rotation. This factor explains $87.15 \%$ of the variance of the variables loading on that factor. The KMO (Kaiser-Meyer-Olkin) measure of sampling adequacy is 0.814 , which comfortably exceeds the minimum KMO score of 0.50 considered necessary to reliably use factor analysis for data analysis. KMO scores over 0.80 are considered very good (Frohlich and Westbrook, 2001, Shou et al., 2013). Similarly, Bartlett's test of sphericity is highly significant ( $p$ value $<0.01$ ), which indicates that the correlation matrix of the variables included in the analysis differs significantly from the identity matrix. Cronbach's alpha test for reliability is greater than 0.70 (the recommended threshold by Numally, 1978; Cronbach, 1951), which is satisfactory. Overall, the high proportion of the variance of the variables explained by the extracted factor, together with the other diagnostics, indicates that the factor analysis is satisfactory and suitable for our analysis. Finally, in a third step, we normalize the estimated SSCM performance variable (SSCM) to the 0 to 100 range.

\subsection{Independent variables}

Following Cheng et al. (2014), we measure the sustainability performance of focal firms directly from ASSET4. Sustainability performance $(S P)$ reflects how well a firm uses management practices to avoid environmental risks in their own operations, and capitalizes on environmental opportunities to generate long term value. Cheng et al. (2014) note that this measurement includes information on energy used, water recycled, carbon emissions, waste 
recycled, and spills and pollution controversies. $S P$ ranges from 0 to 100 , reflecting the relative sustainability performance of the focal firm.

Following previous research (e.g. Brunner et al., 2008, Servaes and Tamayo, 2013), we posit that a firm's marketing expenditure and customer satisfaction/loyalty policies enhance (potential and existing) customer awareness about the firm, which reduces the information gap between the firm and its customers. This makes it more likely that customers will find out about the firm's SSCM involvement, and reward the firm for its SSCM efforts. The idea that marketing, customer satisfaction and loyalty programs supply information about the firm goes back many decades (Nelson, 1974, Bagwell, 2007); and McWilliams and Siegel (2000, 2001) have suggested that media coverage of a firm's corporate social responsibility (CSR) activities increases consumer awareness of CSR performance. This increased consumer awareness increases the demand for socially responsible behaviour by firms and the benefits from engaging in such behaviour. Similarly, Servaes and Tamayo (2013) argue that firm marketing programs improve the firm's information environment and customer awareness. Following Servaes and Tamayo (2013), we note that this prediction does not imply that firms need to market their sustainable and SSCM activities. All that is required is that marketing expenditure and other customer care programs lead to increased awareness of the firm, including its sustainable activities. We measure customer awareness $(C A)$ by the revenue/client loyalty score from ASSET4. According to ASSET4, CA covers the focal firm's performance in customer satisfaction policy, customer communication policy, marketing expenditure, brand value, customer monitoring policy and consumer complaints policy. To capture stakeholder engagement (SE), we follow Cheng et al. (2014), and use the score directly from the ASSET4 dataset. Cheng et al. (2014) suggest that this $S E$ measures "the degree to which the focal firm explains the formal processes in place for engagement with its stakeholders". 


\subsection{Control variables}

We include two control variables, firm size and leverage, which may confound the relationship between the independent variables in our model and the dependent variable. Following Wolf (2013) and Wagner et al. (2012), firm size (Size) is measured by the log of the number of employees. Three reasons highlight the need to control for firm size. First, large firms may have more market power than small firms, and so be more influential with supply chain partners (Ayuso et al., 2013). In contrast, small firms may be more innovative, and therefore more adaptive to customer needs. Second, large firms may be in a better position to provide financial, human, and technological resources to help their supply chain partners improve their sustainability performance (Vachon and Klassen, 2008, Wu et al., 2010). Finally, large firms are more prone to scrutiny by stakeholders, making them more willing to transfer some of this pressure to their supply chain partners (Parmigiani et al., 2011, Hartmann and Moeller, 2014).

We also control for firm leverage (Leverage), which is measured by the focal firm's total debt to equity ratio (Ramdani and Witteloostuijn, 2010), with higher leverage indicating a higher risk of default. Consequently, supply chain partners are more reluctant to invest in a relationship-specific asset with a focal firm that has a high leverage. The focal firm's suppliers may require more favourable contractual terms in their dealings due to the higher perceived risk of default; leading to lower mutual trust and a larger information asymmetry. Empirically, Grant (2003) and Surroca et al. (2010) found that, for industries where strategic alliances and long-term partnerships between suppliers and buyers are more prevalent, firms favour lower debt strategies to signal their willingness to cooperate with their supply chains. 
In addition to the independent variables in our model, there are likely to be unobserved timeinvariant effects on supply chain priorities and practices that vary between industries and countries. Therefore, we include industry $(I)$ and country $(C)$ dummy variables as recommended in previous studies, such as Bozarth et al. (2009) and Wagner et al. (2012). Following Cohen et al. (2013), we dummy-coded our firms into sectors according to the FamaFrench industry classification (Fama and French, 1997, Verwijmeren and Derwall, 2010), and into countries. We also included year fixed effects $(Y)$ to account for transitory economy-wide factors, such as aggregate macroeconomic conditions (Flammer, 2015).

As a robustness test we also control for firm and year fixed effects. The firm fixed effects mitigate endogeneity concerns that our findings might suffer from omitting correlated timeinvariant variables (Cheng et al., 2014). The firm fixed effects model also helps to ensure that our estimated coefficients reflect actual changes within firms over time, and not simply crosssectional correlations. To confirm our choice of a fixed effects model, rather than other models (e.g. a random effects model), we performed the Hausman test, and this test favours a fixed effects model. For brevity, the results of this test are untabulated, but available on request.

\section{Results}

\subsection{Summary statistics}

Table 1 provides descriptive statistics for the entire sample. Panel A presents descriptive statistics for the focal firm's SSCM performance (SSCM), own sustainability capability $(S P)$, customer awareness $(C A)$, stakeholder engagement $(S E)$, Size, and Leverage. Panel B shows the distribution of observations across industries grouped according to the Fama-French industry classification, and panel $\mathrm{C}$ provides the sample distribution across years. The sample includes firms from around the world, with 367 firms in 2002, rising to 2,000 firms in 2015 . 
The increasing number of firms in the ASSET4 database reflects the increasing attention paid to sustainability.

Table 1. Descriptive Statistics

\begin{tabular}{llrl}
\hline Panel A. Summary statistics & & \\
Variable & Observations & Mean & Std. Dev. \\
SSCM & 16,493 & 25.96 & 28.51 \\
SP & 16,493 & 57.49 & 32.23 \\
CA & 16,493 & 53.00 & 28.34 \\
Size & 16,493 & 9.28 & 1.59 \\
Leverage & 16,493 & 0.96 & 23.34 \\
SE & 16,493 & 47.59 & 30.36 \\
\hline
\end{tabular}

Panel B. Sample distribution across sectors

\begin{tabular}{llll} 
Fama-French industry code & Freq. & Percent & Cum. \\
\hline Manufacturing -- Food, Tobacco, Textiles, Apparel, Leather, Toys & 2,177 & 13.20 & 13.20 \\
Manufacturing -- Cars, TV's, Furniture, Household Appliances & 1,029 & 6.24 & 19.44 \\
Manufacturing -- Machinery, Trucks, Planes, Office, Paper, Com Printing & 3,884 & 23.55 & 42.99 \\
Oil, Gas, and Coal Extraction and Products & 1,923 & 11.66 & 54.65 \\
Chemicals and Allied Products & 1,412 & 8.56 & 63.21 \\
Business Equipment -- Computers, Software, and Electronic Equipment & 3,151 & 19.11 & 82.31 \\
Telephone and Television Transmission & 1,370 & 8.31 & 90.62 \\
Healthcare, Medical Equipment, and Drug & 1,547 & 9.38 & 100.00 \\
Total & 16,493 & 100.00 & \\
\hline
\end{tabular}

Panel C. Sample distribution across years

\begin{tabular}{llllllll} 
Year & Freq. & Percent & Cum. & Year & Freq. & Percent & Cum. \\
\hline 2002 & 367 & 2.23 & 2.23 & 2010 & 1,521 & 9.22 & 48.60 \\
2003 & 369 & 2.24 & 4.46 & 2011 & 1,577 & 9.56 & 58.16 \\
2004 & 674 & 4.09 & 8.55 & 2012 & 1,612 & 9.77 & 67.93 \\
2005 & 864 & 5.24 & 13.79 & 2013 & 1,608 & 9.75 & 77.68 \\
2006 & 875 & 5.31 & 19.09 & 2014 & 1,681 & 10.19 & 87.87 \\
2007 & 952 & 5.77 & 24.87 & 2015 & 2,000 & 12.13 & 100.00 \\
2008 & 1,118 & 6.78 & 31.64 & & & & \\
2009 & 1,275 & 7.73 & 39.37 & Total & 16,493 & 100.00 & \\
\hline
\end{tabular}

As panel A shows, the focal firm's capability to manage their own sustainability $($ mean $=57.49)$

is much better than their SSCM performance (mean = 25.96). This suggests that cascading sustainability along the supply chain is more difficult than improving the sustainability of the 
focal firm. In Appendix B we present univariate correlations for all the variables of interest, which shows a correlation of 0.67 between the focal firm's sustainable performance and its SSCM performance.

Table 2 (as well as Figure 2) provides the results of the fixed effects models which tests hypotheses 1 to 3 . These models control for firm size and leverage; and also year, industry and country fixed effects. Models 1 to 4 in Table 2 represent four linear regressions which explain variations in the two outcome variables - the focal firm's' sustainability performance $(S P)$ (equation 1), and their sustainable supply chain performance (SSCM) (equations 2-4).

$$
\begin{aligned}
& S P_{i}=a_{0}+a_{1} C A_{i}+a_{2} \text { Size }_{i}+a_{3} \text { Leverage }_{i}+I+C+Y+\varepsilon_{S P} \\
& \operatorname{SSCM}_{i}=b_{0}+b_{1} C A_{i}+b_{2} \text { Size }_{i}+b_{3} \text { Leverage }_{i}+I+C+Y+\varepsilon_{\text {SSCM1 }} \\
& \operatorname{SSCM}_{\mathrm{i}}=\mathrm{c}_{0}+\mathrm{c}_{1} \mathrm{SP}_{\mathrm{i}}+\mathrm{c}_{2} \text { Size }_{\mathrm{i}}+\mathrm{c}_{3} \text { Leverage }_{\mathrm{i}}+\mathrm{I}+\mathrm{C}+\mathrm{Y}+\varepsilon_{\mathrm{SSCM} 2} \\
& \operatorname{SSCM}_{\mathrm{i}}=\mathrm{d}_{0}+\mathrm{d}_{1} \mathrm{SP}_{\mathrm{i}}+\mathrm{d}_{2} \mathrm{CA}_{\mathrm{i}}+\mathrm{d}_{3} \text { Size }_{\mathrm{i}}+\mathrm{d}_{4} \text { Leverage }_{\mathrm{i}}+\mathrm{I}+\mathrm{C}+\mathrm{Y}+\varepsilon_{\text {SSCM3 }}
\end{aligned}
$$

Columns 1 and 2 show the results for hypothesis 1 (equation 1) and hypothesis 2 (equation 2) respectively. In column 1 the coefficient for $C A$ is positive and highly significant $(0.371, p$ value $<0.01$ ), suggesting that, on average, customer awareness significantly improve the firms' sustainable performance. In column 2 the impact of customer awareness on SSCM performance is also positive and significant $(0.275, p$-value $<0.01)$, but the magnitude of the effect is smaller than that on the firm's own sustainability. Consistent with Wilhelm et al. (2016b), this suggests it is more difficult to incentivise the focal firm to diffuse sustainability to their supply chain, than it is to incentivise them to manage their own sustainability. 
Table 2: Regression Results for Hypotheses 1 to 3

\begin{tabular}{|c|c|c|c|c|}
\hline Variables & $\begin{array}{l}(1) \\
\text { SP }\end{array}$ & $\begin{array}{l}\text { (2) } \\
\text { SSCM }\end{array}$ & $\begin{array}{l}(3) \\
\text { SSCM }\end{array}$ & $\begin{array}{l}\text { (4) } \\
\text { SSCM }\end{array}$ \\
\hline CA & $\begin{array}{l}0.371 * * * \\
(0.00725)\end{array}$ & $\begin{array}{l}0.275^{* * *} * \\
(0.00698)\end{array}$ & & $\begin{array}{l}0.0851 * * * \\
(0.00636)\end{array}$ \\
\hline SP & & & $\begin{array}{l}0.544 * * * \\
(0.00594)\end{array}$ & $\begin{array}{l}0.512 * * * \\
(0.00636)\end{array}$ \\
\hline \multicolumn{5}{|l|}{ Controls } \\
\hline Size & $\begin{array}{l}7.673 * * * \\
(0.140)\end{array}$ & $\begin{array}{l}5.695 * * * \\
(0.135)\end{array}$ & $\begin{array}{l}2.061 * * * \\
(0.123)\end{array}$ & $\begin{array}{l}1.766^{* * * *} \\
(0.124)\end{array}$ \\
\hline Leverage & $\begin{array}{l}-0.00437 \\
(0.00785)\end{array}$ & $\begin{array}{l}-0.0107 \\
(0.00755)\end{array}$ & $\begin{array}{l}-0.00879 \\
(0.00643)\end{array}$ & $\begin{array}{l}-0.00843 \\
(0.00640)\end{array}$ \\
\hline Constant & $\begin{array}{l}-54.46^{* * * *} \\
(13.71)\end{array}$ & $\begin{array}{l}-66.77 * * * \\
(13.19)\end{array}$ & $\begin{array}{l}-41.58 * * * \\
(11.24)\end{array}$ & $\begin{array}{l}-38.89 * * * \\
(11.18)\end{array}$ \\
\hline Observations & 16,493 & 16,493 & 16,493 & 16,493 \\
\hline R-squared & 0.471 & 0.374 & 0.546 & 0.551 \\
\hline Year FE & YES & YES & YES & YES \\
\hline Industry FE & YES & YES & YES & YES \\
\hline Country FE & YES & YES & YES & YES \\
\hline
\end{tabular}

To test hypothesis 3, that the impact of customer awareness on the focal firm's SSCM performance is mediated by the firm's sustainability capability, we follow the procedure outlined by Baron and Kenny (1986). They explain that mediating relationships must satisfy the following conditions: (1) the independent variable $(C A)$ significantly affects the mediator variable $(S P)(0.371, p$-value $<0.01$, in equation 1$)$; (2) the independent variables significantly affect the dependent variable $(S S C M)$ in the absence of the mediator variable $(0.275, p$-value $<0.01$, in equation 2); (3) the mediator variable has a significant effect on the dependent variable $(0.544, p$-value $<0.01$, in equation 3$)$, and (4) the effect of the independent variables on the dependent variable is reduced in the presence of the mediator variable $(0.0851, p$-value $<0.01$, in equation 4). If any of these conditions is not satisfied, there is no mediation (Baron and Kenny, 1986, Zhu et al., 2013). As summarised in Figure 2, all four conditions are met. 
Total effect:

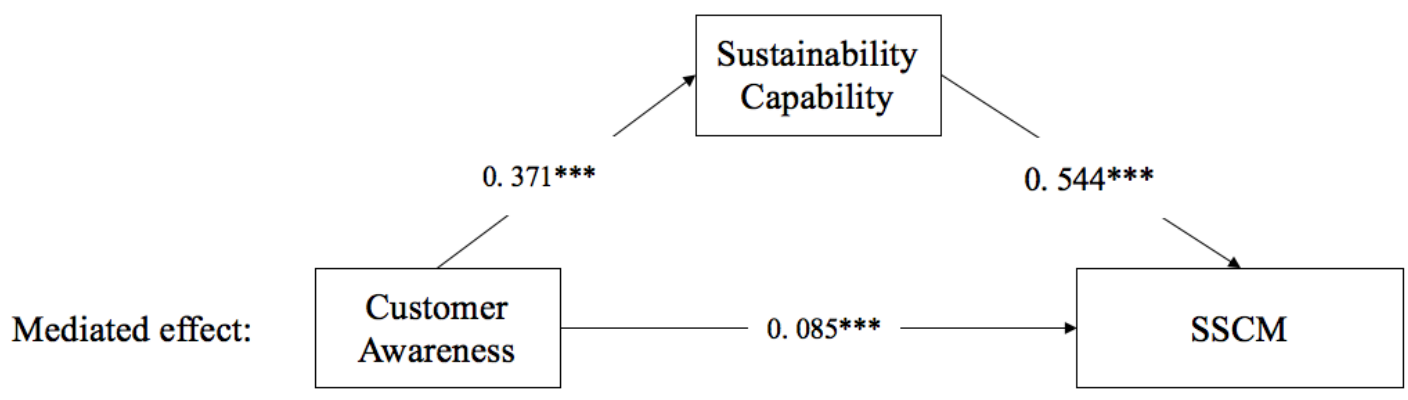

Figure 2. Testing the Mediation Effect of firm's sustainability capability. $* * * \mathrm{p}<0.01$.

The results of columns 1, 2 and 3 of Table 2 correspond to the first three conditions for mediator variable testing. The results in column 4 support the fourth condition that the firms' own sustainability capability has a significant positive effect on their SSCM performance $(0.512, p$ value $<0.01$ ), and the effect of the customer awareness on the SSCM performance shrinks with the addition of the mediator variable. The higher $R^{2}$ value for column $4(55.1 \%)$ indicates that adding the mediator variable increases the explanatory power of the regression.

The Sobel-Goodman mediation test (in Table 3) shows that the mediation effect of the focal firm's sustainability capability is statistically significant, with approximately $70 \%$ of the total effect being mediated. The ratio of the indirect to the direct effect is 2.232 , while the ratio of total to direct effects is 3.232 . 
Table 3 Sobel-Goodman Mediation Test

\begin{tabular}{|c|c|}
\hline Path & Path Coefficient \\
\hline \multicolumn{2}{|l|}{ Mediator: $S P$} \\
\hline Customer awareness-firm's sustainable performance & $\begin{array}{l}0.371 * * * \\
(0.0072)\end{array}$ \\
\hline Firm's sustainable performance — firm's SSCM performance & $\begin{array}{l}0.544 * * * \\
(0.006)\end{array}$ \\
\hline \multicolumn{2}{|l|}{ Indirect effect: } \\
\hline Customer awareness — firm's SSCM performance & $\begin{array}{l}0.190 * * * \\
(0.004)\end{array}$ \\
\hline \multicolumn{2}{|l|}{ Direct effect: } \\
\hline Customer awareness - firm's SSCM performance & $\begin{array}{l}0.085 * * * \\
(0.006)\end{array}$ \\
\hline \multicolumn{2}{|l|}{ Total effect: } \\
\hline Customer awareness - firm's SSCM performance & $\begin{array}{l}0.275 * * * \\
(0.007)\end{array}$ \\
\hline Proportion of total effect that is mediated: & 0.691 \\
\hline Ratio of indirect to direct effect: & 2.232 \\
\hline Ratio of total to direct effect: & 3.232 \\
\hline
\end{tabular}

Table 4 presents a robustness check for hypotheses 1 to 3 . Compared to the baseline regressions in Table 2, the models in Table 4 control for firm fixed effects, and are consistent with those of Table 2. Overall, these results support hypotheses 1 to 3 , and indicate that our findings do not suffer from omitting correlated time-invariant variables.

Table 4 Robustness Check on Hypotheses 1 to 3

\begin{tabular}{|c|c|c|c|c|}
\hline Variables & $\begin{array}{l}(1) \\
\text { SP }\end{array}$ & $\begin{array}{l}2) \\
\text { SSCM } \\
\end{array}$ & $\begin{array}{l}3) \\
\text { SSCM }\end{array}$ & $\begin{array}{l}4) \\
\text { SSCM }\end{array}$ \\
\hline CA & $\begin{array}{l}0.0954 * * * \\
(0.00602)\end{array}$ & $\begin{array}{l}0.0688 * * * \\
(0.00621)\end{array}$ & & $\begin{array}{l}0.0374 * * * \\
(0.00594)\end{array}$ \\
\hline SP & & & $\begin{array}{l}0.336 * * * \\
(0.00812)\end{array}$ & $\begin{array}{l}0.329 * * * \\
(0.00818)\end{array}$ \\
\hline Controls & & & & \\
\hline Size & $\begin{array}{l}3.453 * * * \\
(0.382)\end{array}$ & $\begin{array}{l}-0.903 * * \\
(0.394)\end{array}$ & $\begin{array}{l}-1.830 * * * \\
(0.374)\end{array}$ & $\begin{array}{l}-2.038^{* * *} \\
(0.375)\end{array}$ \\
\hline Leverage & $\begin{array}{l}0.0000646 \\
(0.00488)\end{array}$ & $\begin{array}{l}-0.00669 \\
(0.00503)\end{array}$ & $\begin{array}{l}-0.00694 \\
(0.00478)\end{array}$ & $\begin{array}{l}-0.00671 \\
(0.00477)\end{array}$ \\
\hline Constant & $\begin{array}{l}3.041 \\
(3.533)\end{array}$ & $\begin{array}{l}3.121 \\
(3.645)\end{array}$ & $\begin{array}{l}1.516 \\
(3.459)\end{array}$ & $\begin{array}{l}2.122 \\
(3.455)\end{array}$ \\
\hline Observations & 16,493 & 16,493 & 16,493 & 16,493 \\
\hline R-squared & 0.245 & 0.399 & 0.459 & 0.460 \\
\hline Year FE & YES & YES & YES & YES \\
\hline Firm FE & YES & YES & YES & YES \\
\hline
\end{tabular}


To test hypothesis 4, that stakeholder engagement has a moderating effect on the focal firm's SSCM performance, we add stakeholder engagement $(S E)$ and the interaction of $S P$ and $S E$ to model 4 in Table 2 . This leads to the following two linear equations:

$$
\begin{aligned}
& \operatorname{SSCM}_{\mathrm{i}}=\mathrm{v}_{0}+\mathrm{v}_{1} \mathrm{SP}_{\mathrm{i}}+\mathrm{v}_{2} \mathrm{CA}_{\mathrm{i}}+\mathrm{v}_{3} \mathrm{SE}_{\mathrm{i}}+\mathrm{v}_{4} \text { Size }_{\mathrm{i}}+\mathrm{v}_{5} \text { Leverage }_{\mathrm{i}}+\mathrm{I}+\mathrm{C}+\mathrm{Y}+\varepsilon_{\text {SSCM } 4} \\
& \mathrm{SSCM}_{\mathrm{i}}=\mathrm{v}_{0}+\mathrm{v}_{1} \mathrm{SP}_{\mathrm{i}}+\mathrm{v}_{2} \mathrm{CA}_{\mathrm{i}}+\mathrm{v}_{3} \mathrm{SE}_{\mathrm{i}}+\mathrm{v}_{4} \mathrm{SP}_{\mathrm{i}} \mathrm{SE}_{\mathrm{i}}+\mathrm{v}_{5} \text { Size }_{\mathrm{i}}+\mathrm{v}_{6} \text { Leverage }_{\mathrm{i}}+\mathrm{I}+\mathrm{C}+\mathrm{Y}+ \\
& \varepsilon_{\mathrm{SSCM} 4}
\end{aligned}
$$

Our results appear in Table 5, where column 1 shows the estimated association between $S E$ and SSCM performance. The coefficient on $S E$ is positive and significant $(0.151, p$-value < 0.01 , in equation 5). In column 2 of Table 5, the estimated coefficient on the interaction between $S P$ and $S E$ is positive and significant $(0.00341, p$-value $<0.01$ in equation 6$)$, supporting hypothesis 4 .

Columns 3 and 4 of Table 5 present a robustness check for hypothesis 4 with firm and year fixed effects. Overall, as expected, stakeholder engagement has a significant positive moderating effect on the relationship between the focal firm's own sustainability capability and sustainable supply chain performance. 
Table 5: Regression Results and Robustness Check for Hypothesis 4

\begin{tabular}{|c|c|c|c|c|}
\hline Variables & $\begin{array}{l}\text { (5) } \\
\text { SSCM }\end{array}$ & $\begin{array}{l}\text { (6) } \\
\text { SSCM }\end{array}$ & $\begin{array}{l}\text { (5) } \\
\text { SSCM }\end{array}$ & $\begin{array}{l}\text { (6) } \\
\text { SSCM }\end{array}$ \\
\hline CA & $\begin{array}{l}0.0661 * * * \\
(0.00628)\end{array}$ & $\begin{array}{l}0.0649 * * * \\
(0.00624)\end{array}$ & $\begin{array}{l}0.0306 * * * \\
(0.00589)\end{array}$ & $\begin{array}{l}0.0305 * * * \\
(0.00588)\end{array}$ \\
\hline SP & $\begin{array}{l}0.449 * * * \\
(0.00671)\end{array}$ & $\begin{array}{l}0.329 * * * \\
(0.0108)\end{array}$ & $\begin{array}{l}0.303 * * * \\
(0.00825)\end{array}$ & $\begin{array}{l}0.236 * * * \\
(0.0124)\end{array}$ \\
\hline SE & $\begin{array}{l}0.151 * * * \\
(0.00590)\end{array}$ & $\begin{array}{l}-0.114 * * * \\
(0.0196)\end{array}$ & $\begin{array}{l}0.108 * * * \\
(0.00628)\end{array}$ & $\begin{array}{l}-0.0412 * \\
(0.0217)\end{array}$ \\
\hline $\mathrm{SE} * \mathrm{SP}$ & & $\begin{array}{l}0.00341 * * * \\
(0.000241)\end{array}$ & & $\begin{array}{l}0.00190 * * * \\
(0.000266)\end{array}$ \\
\hline Control & & & & \\
\hline Size & $\begin{array}{l}1.519 * * * \\
(0.122)\end{array}$ & $\begin{array}{l}1.411 * * * \\
(0.122)\end{array}$ & $\begin{array}{l}-1.892 * * * \\
(0.371)\end{array}$ & $\begin{array}{l}-1.802 * * * \\
(0.371)\end{array}$ \\
\hline Leverage & $\begin{array}{l}-0.00803 \\
(0.00627)\end{array}$ & $\begin{array}{l}-0.00813 \\
(0.00623)\end{array}$ & $\begin{array}{l}-0.00631 \\
(0.00472)\end{array}$ & $\begin{array}{l}-0.00639 \\
(0.00471)\end{array}$ \\
\hline Constant & $\begin{array}{l}-20.44 * * * \\
(5.334)\end{array}$ & $\begin{array}{l}-9.530^{*} \\
(5.357)\end{array}$ & $\begin{array}{l}-1.640 \\
(3.428)\end{array}$ & $\begin{array}{l}2.799 \\
(3.477)\end{array}$ \\
\hline Observations & 16,493 & 16,493 & 16,493 & 16,493 \\
\hline R-squared & 0.568 & 0.573 & 0.471 & 0.473 \\
\hline Year FE & YES & YES & YES & YES \\
\hline Firm FE & NO & $\mathrm{NO}$ & YES & YES \\
\hline Industry FE & YES & YES & NO & NO \\
\hline Country FE & YES & YES & NO & NO \\
\hline
\end{tabular}

Standard errors in parentheses*** $\mathrm{p}<0.01, * * \mathrm{p}<0.05, * \mathrm{p}<0.1$

\section{Discussion and Conclusions}

This study of how sustainability develops both within the focal firm, and via sustainable supply chain management (SSCM), makes three points. First, the results suggest that public awareness, as proxied by a firm's marketing expenditure and customer satisfaction policy, is an essential driver that motivates firms to develop their sustainability capability, and to disseminate sustainability to their supply chain partners via SSCM. Second, a firm's own sustainability capability provides the know-how foundation for the development of SSCM. Third, stakeholder engagement is a moderating factor which improves a firm's information environment, and encourages firms to develop SSCM. 
The main theoretical contribution of this paper is the complex interaction between the focal firm's own sustainability capability and SSCM; and its information environment and stakeholder engagement. On the basis of our results we suggest that, when theorising and testing the impact of various drivers and enablers on the development of SSCM, the focal firm's public awareness and sustainability capability should be taken into account. This finding complements prior research (Klassen and Vachon, 2003, Flynn et al., 2010, Gualandris and Kalchschmidt, 2014), which suggests that "having your house in order and building internal resources usually sets the stage for increased requirements and adoption for external environmentally oriented organizational practices" (Zhu et al., 2013). By focussing on supply chain sustainability, our results also complement and extend prior research (Servaes and Tamayo, 2013) which suggests that customer awareness is one of the main channels through which sustainable activities affect firm value. Our finding is consistent with theoretical work suggesting that without awareness, customers are unable to reward a firm's involvement in sustainability (McWilliams and Siegel, 2001, Sen and Bhattacharya, 2001).

Our conclusions differ from those derived from the Gualandris and Kalchschmidt (2014) model. They examined a sample of 77 Italian firms, and argued that customer pressure may (indirectly) increase SSCM. Their argument relies on customers' specific sustainability requirements, which are measured as “customers' requests and requirements to improve a firm's environmental and social performance" (Gualandris and Kalchschmidt, 2014, p.94). Our argument, on the other hand, focuses on a firm's information environment, which does not imply that firms need to market or advertise their sustainable or SSCM activities. All that is required is that marketing expenditure and customer satisfaction programs lead to increased public awareness of the firm. 
Although explorative in its nature, our study of stakeholder engagement provides new insights to explain why some firms are more effective than others in converting their internal sustainability activities into external SSCM, and in responding to external pressures. This finding challenge that of Wolf (2013) that stakeholder engagement does not have a moderating role in promoting SSCMs. Instead, we find that firms react to stakeholder engagement in their SSCM strategies and practices. We suggest that the information environment, which is not examined in Wolf (2013), represents an important channel for stakeholder influence in an SSCM context. Our results on the moderating effects of stakeholder engagement confirm the hypothesis that, when there is greater stakeholder engagement, this increases SSCM performance.

SSCM is far from being a novel subject, and hundreds of works have been published over the last decade highlighting the relevance of this topic. However, many hypothesized relationships in the area of SSCM are still under-researched (Ashby et al., 2012), This is because the measurement of SSCM is still being developed (Ortas et al. (2014), the presence of methodological concerns, particularly model misspecification (Margolis and Walsh, 2001), and because inductive research methods such as case studies dominate the SSCM field (Seuring and Müller, 2008, Ashby et al., 2012). Although case studies provide good insight into complex contemporary phenomena (Yin, 2009) and have revealed relevant findings in managing SSCMs, they often lack generalizability to other contexts (Eisenhardt, 1989). The SSCM literature lacks global studies (Ortas et al., 2014). In this paper, we use a large global sample to enrich the sample generalizability of SSCM research, and a firm fixed effects model to address model misspecification problems. We build on and enrich the application of the rigorous SSCM measurement developed by Ortas et al. (2014) by linking the measurement of stakeholder engagement developed in the strategic management literature with the information 
environment. In previous quantitative studies SSCM data has been obtained through questionnaire surveys, with samples confined to a given sector (Ayuso et al., 2013). Instead, we use the ASSET4 database, which contains only publicly available information, and a large dataset of 2,206 firms across different sectors and counties.

There are two views of the motivation for sustainability practices, including SSCM, - the agency view and the strategic view. The agency view is that sustainability practices are financed by managerial rents that a firm's executives choose to divert to social and environmental initiatives for their personal interest ${ }^{2}$. The strategic view suggests that engaging in sustainability practices provides firms with a competitive advantage. If the motivation for sustainability initiatives is to satisfy the personal goals of a firm's executives, a more transparent environment should reduce sustainability and SSCM, as the firm will be unwilling to have these activities publicised. However, if sustainability and SSCM are motivated by gaining a competitive advantage, a more transparent information environment will encourage sustainability and SSCM activities. By providing evidence that firms operating in a more transparent environment are more socially responsible in their own operations, as well as in SSCR, our results enrich the debate on the motivation of sustainability and are consistent with the strategic view.

Our results have important managerial implications for practice concerning SSCM. The extent to which a focal firm responds to their customers' sustainability expectations depends on the resources and knowledge available to the focal firm. Once a firm has developed an advanced

\footnotetext{
${ }^{2}$ Consider the following excerpt from the Lys et al. (2015): "Mr. Kozlowski was known for spending his own time and money on worthy causes. But he was also very generous with Tyco's money, donating tens of millions of corporate dollars to charities he favoured - often getting credit in his own name rather than Tyco's. A Maine private school attended by his daughters got \$1.7 million in Tyco money for its Kozlowski Athletic Center, while his alma mater, New Jersey's Seton Hall University, received a \$5 million Tyco pledge for Kozlowski Hall.”
} 
knowledge of environmental and social management in its own operations, managers are in a position to seek out opportunities in their supply chain, and to find appropriate support within their organisations.

Firms engaging in SSCM activities often find it difficult to assess whether these activities create value. Our findings suggest that customer awareness is one of the main channels through which SSCM creates value, as greater customer awareness increases the likelihood that customers will reward the firm for its SSCM efforts. If a firm engages in SSCM, but does not operate in a marketing-intensive environment, its management should reconsider its SSCM efforts, or search for opportunities to increase public awareness of the firm. We believe that our evidence may help them in making this assessment.

Our moderating variable analysis has found that greater stakeholder engagement is an essential moderator for the development of SSCM. Superior stakeholder engagement enhances the stakeholder relationship and, as firms becomes more transparent and accountable, this reduces information asymmetries. Therefore, in addition to increasing public awareness via the customer channel, the key to achieving superior SSCM is to broaden the stakeholder network, and to increase the transparency and public visibility of the focal firm. This offers a set of priorities for managers.

\section{Limitations}

As with any research, our study has some limitations which provide opportunities for future research. First, although our large cross-industry-country sample provides statistical robustness and generality; future research could investigate whether these global results apply to specific industries and nations, allowing greater control over the contextual and operational 
environment. Second, the environmental dimension of sustainability has been studied in this research, and there are also social dimensions to SSCM, such as occupational health and safety and child labour (Seuring and Müller, 2008, Mueller et al., 2009, Touboulic and Walker, 2015). Future studies could also test whether the effectiveness of the information environment and stakeholder engagement differs as between social and environmental sustainability. Third, future research could identify specific focal firm-supplier relationships so that allowance can be made for supplier dependency, i.e. the share of a focal firm's supplies coming from a particular supplier. ${ }^{3}$ Finally, Gong et al. (2016) and Li et al. (2017) recognise that not all stakeholders have a similar reaction to a firm's environmental and social activities. Some stakeholders may be sensitive to the sustainability performance of only a sub-set of firms, or only to a particular type of sustainability. Thus, we expect future research to pursue a more finely grained analysis of stakeholder engagement.

\footnotetext{
${ }^{3}$ We thank an anonymous reviewer for this point.
} 


\section{Appendix A: The Indicator Variables Used in the Factor Analysis and their Loadings}

\begin{tabular}{|c|c|c|}
\hline Indicators & Description & Loading \\
\hline SSM1 & $\begin{array}{l}\text { Does the firm provide training on environmental, social or governance factors for its } \\
\text { suppliers? }\end{array}$ & $0.798 * * *$ \\
\hline SSM2 & Does the firm have a policy to lessen the environmental impact of its supply chain? & $0.926 * * *$ \\
\hline SSM3 & $\begin{array}{l}\text { Does the firm describe, claim to have or, mention processes in place to include its supply } \\
\text { chain in the firm's efforts to lessen its overall environmental impact? }\end{array}$ & $0.941 * * *$ \\
\hline SSM4 & $\begin{array}{l}\text { Does the firm claim to use key performance indicators (KPI) or balanced scorecard to } \\
\text { monitor the environmental impact of its supply chain? }\end{array}$ & $0.778 * * *$ \\
\hline SSM5 & $\begin{array}{l}\text { Does the firm use environmental criteria (ISO 14000, energy consumption, etc.) in the } \\
\text { selection process of its suppliers or sourcing partners? }\end{array}$ & $0.980 * * *$ \\
\hline SSM6 & $\begin{array}{l}\text { Does the firm report or show to be ready to end a partnership with a sourcing partner, if } \\
\text { environmental criteria are not met? }\end{array}$ & \\
\hline
\end{tabular}

Largest eigenvalue $=4.609$, Explained variance $=87.15 \%$, Kaiser-Meyer-Olkin test $=0.814$, Bartlett's sphericity test $=\chi^{2}=39071.299 * * *(15 \mathrm{df}, * * * \mathrm{p}<0.01)$, Cronbach's alpha $=0.7997, * * * \mathrm{p}<0.01, * *$ $\mathrm{p}<0.05, * \mathrm{p}<0.1$ 
Appendix B: Correlation Matrix for the Dependent and Explanatory Variables

\begin{tabular}{lllllll}
\hline & SSCM & SP & CA & Size & Leverage & SE \\
\hline SSCM & 1.0000 & & & & & \\
SP & 0.6706 & 1.0000 & & & & \\
CA & 0.4198 & 0.5018 & 1.0000 & & & \\
Size & 0.3736 & 0.4618 & 0.3726 & 1.0000 & & \\
Leverage & -0.0097 & -0.0063 & -0.0052 & 0.0036 & 1.0000 & \\
SE & 0.5045 & 0.5051 & 0.3600 & 0.2725 & -0.0032 & 1.0000 \\
\hline
\end{tabular}




\section{References}

Ashby, A., Leat, M. \& Hudson- Smith, M. 2012. Making Connections: A Review of Supply Chain Management and Sustainability Literature. Supply Chain Management: An International Journal, 17(5), 497-516.

Ayuso, S., Roca, M. \& Colomé, R. 2013. Smes as "Transmitters" of Csr Requirements in the Supply Chain. Supply Chain Management: An International Journal, 18(5), 497-508.

Bagwell, K. 2007. The Economic Analysis of Advertising. Handbook of industrial organization, 3, 1701-1844.

Baron, D. P. 2001. Private Politics, Corporate Social Responsibility, and Integrated Strategy. Journal of Economics \& Management Strategy, 10(1), 7-45.

Baron, R. M. \& Kenny, D. A. 1986. The Moderator-Mediator Variable Distinction in Social Psychological Research: Conceptual, Strategic, and Statistical Considerations. Journal of personality and social psychology, 51(6), 1173.

Bénabou, R. \& Tirole, J. 2010. Individual and Corporate Social Responsibility. Economica, 77(305), 1-19.

Berrone, P., Fosfuri, A., Gelabert, L. \& Gomez-Mejia, L. R. 2013. Necessity as the Mother of "Green' Inventions: Institutional Pressures and Environmental Innovations. Strategic Management Journal, 34(8), 891-909.

Berrone, P. \& Gomez-Mejia, L. R. 2009. Environmental Performance and Executive Compensation: An Integrated Agency-Institutional Perspective. Academy of Management Journal, 52(1), 103-126.

Bhakoo, V. \& Choi, T. 2013. The Iron Cage Exposed: Institutional Pressures and Heterogeneity across the Healthcare Supply Chain. Journal of Operations Management, 31(6), 432449.

Bhattacharya, C. B. \& Sen, S. 2004. Doing Better at Doing Good: When, Why, and How Consumers Respond to Corporate Social Initiatives. California Management Review, 47(1), 9-24.

Bozarth, C. C., Warsing, D. P., Flynn, B. B. \& Flynn, E. J. 2009. The Impact of Supply Chain Complexity on Manufacturing Plant Performance. Journal of Operations Management, 27(1), 78-93.

Brunner, T. A., Opwis, K. \& Stöcklin, M. 2008. Satisfaction, Image and Loyalty: New Versus Experienced Customers. European Journal of Marketing, 42(9/10), 1095-1105.

Carter, C. R. \& Easton, P. L. 2011. Sustainable Supply Chain Management: Evolution and Future Directions. International Journal of Physical Distribution \& Logistics Management, 41(1), 46-62.

Chatterji, A. K. \& Fabrizio, K. R. 2014. Using Users: When Does External Knowledge Enhance Corporate Product Innovation? Strategic Management Journal, 35(10), 14271445.

Cheng, B., Ioannou, I. \& Serafeim, G. 2014. Corporate Social Responsibility and Access to Finance. Strategic Management Journal, 35(1), 1-23.

Choi, T. Y. \& Hong, Y. 2002. Unveiling the Structure of Supply Networks: Case Studies in Honda, Acura, and Daimlerchrysler. Journal of Operations Management, 20(5), 469493.

Cohen, J., Cohen, P., West, S. G. \& Aiken, L. S. 2013. Applied Multiple Regression/Correlation Analysis for the Behavioral Sciences, Routledge.

Corbett, C. J. 2006. Global Diffusion of ISO 9000 Certification through Supply Chains. M\&Som-Manufacturing \& Service Operations Management, 8(4), 330-350.

Corbett, C. J. \& Kirsch, D. A. 2001. International Diffusion of ISO 14000 Certification. Production and Operations Management, 10(3), 327-342. 
Cronbach, L. J. 1951. Coefficient Alpha and the Internal Structure of Tests. Psychometrika, 16(3), 297-334.

De Villiers, C., Naiker, V. \& Van Staden, C. J. 2011. The Effect of Board Characteristics on Firm Environmental Performance. Journal of Management, 37(6), 1636-1663.

Delmas, M. 2001. Stakeholders and Competitive Advantage: The Case of ISO 14001. Production and Operations Management, 10(3), 343-358.

Eccles, R. G., Ioannou, I. \& Serafeim, G. 2014. The Impact of Corporate Sustainability on Organizational Processes and Performance. Management Science, 60(11), 2835-2857.

Eisenhardt, K. M. 1989. Agency Theory: An Assessment and Review. Academy of Management Review, 14(1), 57-74.

Esty, D. \& Winston, A. 2009. Green to Gold: How Smart Companies Use Environmental Strategy to Innovate, Create Value, and Build Competitive Advantage, John Wiley \& Sons.

Fama, E. F. \& French, K. R. 1997. Industry Costs of Equity. Journal of Financial Economics, 43(2), 153-193.

Ferrell, A., Liang, H. \& Renneboog, L. 2016. Socially Responsible Firms. Journal of Financial Economics, 122(3), 585-606.

Flammer, C. 2015. Does Product Market Competition Foster Corporate Social Responsibility? Evidence from Trade Liberalization. Strategic Management Journal, 36(10), 14691485.

Flynn, B. B., Huo, B. \& Zhao, X. 2010. The Impact of Supply Chain Integration on Performance: A Contingency and Configuration Approach. Journal of Operations Management, 28(1), 58-71.

Freeman, R. E. 1984. Strategic Management: A Stakeholder Approach

Freeman, R. E. \& Velamuri, S. R. 2006. A New Approach to Csr: Company Stakeholder Responsibility. Corporate Social Responsibility. Springer.

Frohlich, M. T. \& Westbrook, R. 2001. Arcs of Integration: An International Study of Supply Chain Strategies. Journal of Operations Management, 19(2), 185-200.

Frooman, J. 1999. Stakeholder Influence Strategies. Academy of Management Review, 24(2), 191-205.

Gavronski, I., Klassen, R. D., Vachon, S. \& Nascimento, L. F. M. D. 2011. A Resource-Based View of Green Supply Management. Transportation Research Part E: Logistics and Transportation Review, 47(6), 872-885.

Gold, S., Trautrims, A. \& Trodd, Z. 2015. Modern Slavery Challenges to Supply Chain Management. Supply Chain Management: An International Journal, 20(5), 485-494.

Gong, M., Simpson, A., Koh, L. \& Tan, K. 2016. Inside Out: The Interrelationships of Sustainable Performance Metrics and Its Effect on Business Decision Making: Theory and Practice.

Grant, R. M. 2003. Strategic Planning in a Turbulent Environment: Evidence from the Oil Majors. Strategic Management Journal, 24(6), 491-517.

Greenpeace. 2011. Dirty Laundry: Unravelling the Corporate Connections to Toxic Water Pollution in China. Available: http://www.greenpeace.org/international/Global/international/publications/toxics/Wat er\%202011/dirty-laundry-12pages.pdf [Accessed 15 July 2017].

Grimm, J. H., Hofstetter, J. S. \& Sarkis, J. 2014 . Critical Factors for Sub-Supplier Management: A Sustainable Food Supply Chains Perspective. International Journal of Production Economics, 152, 159-173.

Gualandris, J. \& Kalchschmidt, M. 2014. Customer Pressure and Innovativeness: Their Role in Sustainable Supply Chain Management. Journal of Purchasing and Supply Management, 20(2), 92-103. 
Gualandris, J., Klassen, R. D., Vachon, S. \& Kalchschmidt, M. 2015. Sustainable Evaluation and Verification in Supply Chains: Aligning and Leveraging Accountability to Stakeholders. Journal of Operations Management, 38, 1-13.

Hart, S. L. 1995. A Natural-Resource-Based View of the Firm. Academy of Management Review, 20(4), 986-1014.

Hartmann, J. \& Moeller, S. 2014. Chain Liability in Multitier Supply Chains? Responsibility Attributions for Unsustainable Supplier Behavior. Journal of Operations Management, 32(5), 281-294.

Henriques, I. \& Sadorsky, P. 1999. The Relationship between Environmental Commitment and Managerial Perceptions of Stakeholder Importance. Academy of Management Journal, 42(1), 87-99.

Hofmann, H., Schleper, M. C. \& Blome, C. 2018. Conflict Minerals and Supply Chain Due Diligence: An Exploratory Study of Multi-Tier Supply Chains. Journal of Business Ethics, 147(1), 115-141.

Ioannou, I. \& Serafeim, G. 2012. What Drives Corporate Social Performance? The Role of Nation-Level Institutions. Journal of International Business Studies, 43(9), 834-864.

Jenkins, H. 2004. A Critique of Conventional Csr Theory: An Sme Perspective. Journal of General Management, 29(4), 37-57.

Jo, H. \& Kim, Y. 2007. Disclosure Frequency and Earnings Management. Journal of Financial Economics, 84(2), 561-590.

Jo, H. \& Kim, Y. 2008. Ethics and Disclosure: A Study of the Financial Performance of Firms in the Seasoned Equity Offerings Market. Journal of Business Ethics, 80(4), 855-878.

Kannan, D. 2017. Role of Multiple Stakeholders and the Critical Success Factor Theory for the Sustainable Supplier Selection Process. International Journal of Production Economics.

Klassen, R. D. \& Vachon, S. 2003. Collaboration and Evaluation in the Supply Chain: The Impact on Plant-Level Environmental Investment. Production and Operations Management, 12(3), 336-352.

Koh, S. C. L., Gunasekaran, A. \& Tseng, C. S. 2012. Cross-Tier Ripple and Indirect Effects of Directives Weee and Rohs on Greening a Supply Chain. International Journal of Production Economics, 140(1), 305-317.

Langheinrich, M. \& Karjoth, G. 2010. Social Networking and the Risk to Companies and Institutions. Information Security Technical Report, 15(2), 51-56.

Lee, T., Yao, R. \& Coker, P. 2014. An Analysis of Uk Policies for Domestic Energy Reduction Using an Agent Based Tool. Energy Policy, 66, 267-279.

Li, Y., Gong, M., Zhang, X. \& Koh, L. 2017. The Impact of Environmental, Social, and Governance Disclosure on Firm Value: The Role of Ceo Power.

Liang, H. a. O. \& Renneboog, L. U. C. 2017. On the Foundations of Corporate Social Responsibility. The Journal of Finance, 72(2), 853-910.

Lys, T., Naughton, J. P. \& Wang, C. 2015. Signaling through Corporate Accountability Reporting. Journal of Accounting and Economics, 60(1), 56-72.

Margolis, J. D. \& Walsh, J. P. 2001. People and Profits?: The Search for a Link between a Company's Social and Financial Performance, Psychology Press.

Mcwilliams, A. \& Siegel, D. 2000. Corporate Social Responsibility and Financial Performance: Correlation or Misspecification? Strategic Management Journal, 21(5), 603-609.

Mcwilliams, A. \& Siegel, D. 2001. Corporate Social Responsibility: A Theory of the Firm Perspective. Academy of management review, 26(1), 117-127.

Morais, D. O. C. \& Silvestre, B. S. 2018. Advancing Social Sustainability in Supply Chain Management: Lessons from Multiple Case Studies in an Emerging Economy. Journal of Cleaner Production, 199, 222-235. 
Mueller, M., Dos Santos, V. G. \& Seuring, S. 2009. The Contribution of Environmental and Social Standards Towards Ensuring Legitimacy in Supply Chain Governance. Journal of Business Ethics, 89(4), 509-523.

Nelson, P. 1974. Advertising as Information. Journal of Political Economy, 82(4), 729-754.

Numally, J. C. 1978. Psychometric Theory. NY: McGraw-Hill.

O'riordan, L. \& Fairbrass, J. 2008. Corporate Social Responsibility (Csr): Models and Theories in Stakeholder Dialogue. Journal of Business Ethics, 83(4), 745-758.

Ortas, E., Stefan Schaltegger, P. R. B. D., M. Moneva, J. \& Álvarez, I. 2014. Sustainable Supply Chain and Company Performance. Supply Chain Management: An International Journal, 19(3), 332-350.

Orzes, G., Jia, F., Sartor, M. \& Nassimbeni, G. 2017. Performance Implications of SA8000 Certification. International Journal of Operations \& Production Management, 37(11), 1625-1653.

Park, B. I. \& Ghauri, P. N. 2015. Determinants Influencing Csr Practices in Small and Medium Sized Mne Subsidiaries: A Stakeholder Perspective. Journal of World Business, 50(1), 192-204.

Parmigiani, A., Klassen, R. D. \& Russo, M. V. 2011. Efficiency Meets Accountability: Performance Implications of Supply Chain Configuration, Control, and Capabilities. Journal of Operations Management, 29(3), 212-223.

Plambeck, E., Lee, H. L. \& Yatsko, P. 2012. Improving Environmental Performance in Your Chinese Supply Chain. MIT Sloan Management Review, 53(2), 43-+.

Plambeck, E. L. 2012. Reducing Greenhouse Gas Emissions through Operations and Supply Chain Management. Energy Economics, 34, S64-S74.

Ramdani, D. \& Witteloostuijn, A. V. 2010. The Impact of Board Independence and CEO Duality on Firm Performance: A Quantile Regression Analysis for Indonesia, Malaysia, South Korea and Thailand. British Journal of Management, 21(3), 607-627.

Scherer, A. G. 2018. Theory Assessment and Agenda Setting in Political Csr: A Critical Theory Perspective. International Journal of Management Reviews, 20(2), 387-410.

Schuler, D. A. \& Cording, M. 2006. A Corporate Social Performance-Corporate Financial Performance Behavioral Model for Consumers. Academy of Management Review, 31(3), 540-558.

Semenova, N. \& Hassel, L. G. 2015. On the Validity of Environmental Performance Metrics. Journal of Business Ethics, 132(2), 249-258.

Sen, S. \& Bhattacharya, C. B. 2001. Does Doing Good Always Lead to Doing Better? Consumer Reactions to Corporate Social Responsibility. Journal of Marketing Research, 38(2), 225-243.

Servaes, H. \& Tamayo, A. 2013. The Impact of Corporate Social Responsibility on Firm Value: The Role of Customer Awareness. Management Science, 59(5), 1045-1061.

Seuring, S. \& Müller, M. 2008. From a Literature Review to a Conceptual Framework for Sustainable Supply Chain Management. Journal of Cleaner Production, 16(15), 16991710.

Shou, Y., Feng, Y., Zheng, J., Wang, G. \& Yeboah, N. E. 2013. Power Source and Its Effect on Customer-Supplier Relationships: An Empirical Study in Yangtze River Delta. International Journal of Production Economics, 146(1), 118-128.

Surroca, J., Tribó, J. A. \& Waddock, S. 2010. Corporate Responsibility and Financial Performance: The Role of Intangible Resources. Strategic Management Journal, 31(5), 463-490.

Tang, C. S. 2008. Making Products Safe: Process and Challenges. International Commerce Review, 8(1), 48-55. 
Touboulic, A. \& Walker, H. 2015. Theories in Sustainable Supply Chain Management: A Structured Literature Review. International Journal of Physical Distribution \& Logistics Management, 45(1/2), 16-42.

Vachon, S. \& Klassen, R. D. 2008. Environmental Management and Manufacturing Performance: The Role of Collaboration in the Supply Chain. International Journal of Production Economics, 111(2), 299-315.

Van Tulder, R., Van Wijk, J. \& Kolk, A. 2009. From Chain Liability to Chain Responsibility. Journal of Business Ethics, 85(2), 399-412.

Verwijmeren, P. \& Derwall, J. 2010. Employee Well-Being, Firm Leverage, and Bankruptcy Risk. Journal of Banking \& Finance, 34(5), 956-964.

Vilanova, M., Lozano, J. M. \& Arenas, D. 2009. Exploring the Nature of the Relationship between Csr and Competitiveness. Journal of Business Ethics, 87(1), 57-69.

Wagner, S. M., Grosse-Ruyken, P. T. \& Erhun, F. 2012. The Link between Supply Chain Fit and Financial Performance of the Firm. Journal of Operations Management, 30(4), 340-353.

Wilhelm, M., Blome, C., Wieck, E. \& Xiao, C. Y. 2016a. Implementing Sustainability in MultiTier Supply Chains: Strategies and Contingencies in Managing Sub-Suppliers. International Journal of Production Economics, 182, 196-212.

Wilhelm, M. M., Blome, C., Bhakoo, V. \& Paulraj, A. 2016b. Sustainability in Multi-Tier Supply Chains: Understanding the Double Agency Role of the First-Tier Supplier. Journal of Operations Management, 41, 42-60.

Wolf, J. 2013. The Relationship between Sustainable Supply Chain Management, Stakeholder Pressure and Corporate Sustainability Performance. Journal of Business Ethics, 119(3), 317-328.

Wu, Z., Choi, T. Y. \& Rungtusanatham, M. J. 2010. Supplier-Supplier Relationships in BuyerSupplier-Supplier Triads: Implications for Supplier Performance. Journal of Operations Management, 28(2), 115-123.

Yin, R. K. 2009. Case Study Research, Design \& Methods 4th Ed, London and Singapore, Sage.

Zhu, Q., Cordeiro, J. \& Sarkis, J. 2013. Institutional Pressures, Dynamic Capabilities and Environmental Management Systems: Investigating the Iso 9000 - Environmental Management System Implementation Linkage. Journal of Environmental Management, 114, 232-242.

Zhu, Q., Sarkis, J. \& Lai, K.-H. 2012. Examining the Effects of Green Supply Chain Management Practices and Their Mediations on Performance Improvements. International Journal of Production Research, 50(5), 1377-1394.

Zu, X. \& Kaynak, H. 2012. An Agency Theory Perspective on Supply Chain Quality Management. International Journal of Operations \& Production Management, 32(4), 423-446. 